I Universidade Federal Fluminense (UFF), Programa de Pós-Graduação

em Sociologia, Niterói, RJ, Brasil.

cmonteiro@id.uff.br

https://orcid.org/o0oo-o0oI-82 I0-0942

I I Universidade Federal Fluminense (UFF), Programa de Pós-Graduação

em Sociologia, Niterói, RJ e Programa de Pós-Graduação em

Administração, Volta Redonda, RJ, Brasil.

raphaeljonathas@id.uff.br

Cristiano Monteiro'

https://orcid.org/o0oo-000I-9702-05I5

Raphael Lima"

\title{
EMBEDDEDNESS AND DISEMBEDDEDNESS IN ECONOMIC SOCIOLOGY IN THREE TIME PERIODS*
}

Karl Polanyi's analysis of the market as a key institution of capitalist society, combined with his critical dialogue with Marxism, make him essential reading for practitioners of economic sociology. Even when he turned to the analysis of non-capitalist societies (Polanyi, I977; Polanyi, Arensberg \& Pearson, 1957), his efforts were primarily aimed at defining the specificity of the market system vis-à-vis other forms of organizing the economy. Polanyi was born in Hungary, then passed through Vienna, a city he was eventually forced to leave due to the rise in antisemitism and fascism in 1933 . He went to England where he lectured in economic history, before moving to the United States and subsequently to Canada (Benjamin, 20I2). His circulation among economists, sociologists, anthropologists, and historians was facilitated by the wide-ranging influence of his masterpiece, The great transformation (Polanyi, 200I), a landmark in the critique of economic liberalism and a precursor in the use of the concept of embeddedness. Polanyi's contemporary readers have tried, each in their own way, to develop the implications of the concept of embeddedness and other aspects of his work - for example, the notion of countermovements in response to deregulation of the market - by shedding light on the dislocations between embeddedness and disembeddedness, the main topic to be explored in this article.

The concept of embeddedness has attracted both interest and criticism from economic sociologists. Inspired by the seminal article by Mark Granovetter (I985), a number of authors who participated in the intellectual enterprise 
of the New Economic Sociology saw it as a central concept, associated with the more general notion of the "social construction of the economy" (Swedberg \& Granovetter, I992; Swedberg, 2003: 34; Steiner, I999: 44-73). As economic sociology grew in popularity among social scientists, they started paying closer attention to the multiple meanings the concept had acquired in Polanyi's own work (Polanyi, 200I, I 977) as well as in the interpretation advanced by Granovetter (1985). Along these lines, Krippner (200I), Krippner and Alvarez (2007) and Gemici (2008) approached the idea critically, mainly due to its continuing insistence on separating the economic and social spheres, a limitation that, they argued, the concept ultimately failed to overcome. For these authors, the concept of embeddedness may well have been useful to economic sociology's initial critique of neoclassical economics and its presuppositions concerning the atomization of agents and a market functioning devoid of any kind of social connection. What the discipline lacked, however, was a common theoretical ground on which market functioning could itself be elaborated, a shortcoming that the concept of embeddedness tended to reinforce rather than overcome.

The present article contributes to this debate on the concept of embeddedness by incorporating more recent developments in economic sociology and related disciplines, setting out to argue that the concept remains relevant, albeit in a different sense to the one that informed the context of the New Economic Sociology. It hypothesizes that the continuing relevance of embeddedness resides in its connection with the correlate concept of disembeddedness, which grew in importance as the Polanyian debate became detached from the agenda of the New Economic Sociology, as inspired by Granovetter, and veered toward topics such as the relationship between state and market, development, and, especially, neoliberalism. This aim in mind, the article presents the recent development of economic sociology in three time periods, roughly organized in decades as follows: TI - I980s and I990s; T2-2000s; T3-20I0s. The division into decades is somewhat arbitrary, of course, and does not imply any clear linearity or watertight positions concerning the way the debate has evolved. Instead, this division is intended to highlight specific shifts in the debate on embeddedness (and disembeddedness), as presented below. It also recognizes the existence of emergent tendencies that accumulate, co-exist - or even converge - and form zones of intersection or opposition during the period under analysis. This exercise should help illuminate questions, raising new hypotheses and stimulating reflection on topics relevant to the field of economic sociology and connected to the concept of embeddedness. ${ }^{\mathrm{I}}$

Finally, the article places special emphasis on the debate surrounding embeddedness versus disembeddedness by comparing different approaches to neoliberalism, interpreted both as a kind of economic policy (as stressed in T2) and as a moral-normative system (as stressed in T3). By bringing these different perspectives on neoliberalism together, the article seeks to discuss questions 
deeply relevant to the latter, such as the expectation of a "return of the state" (see Block, 200I) or a possible revitalization of civil society (Crouch, 20I I) as paths to overcome the negative effects of the expansion of the market into social life. The focus on the normative (Dardot \& Laval, 20I0) and performative (Callon, I998) dimensions of economics acknowledges the fact that the logic of the market tends to spread throughout society in a way that puts on hold the (presumed) contradiction between state and market, or between market and the interests of civil society agents, such as workers and popular classes. In this sense, the article looks at questions raised by the $\mathrm{T}_{3}$ debate in order to reflect on the challenges posed to the reconstruction of social solidarity in a context where there seems to exist more alignment than contradiction between the interests of civil society and the market logic.

\section{T1 - EMBEDDEDNESS AS "SOCIAL CONSTRUCTION OF THE ECONOMY"}

Contemporary economic sociology, during the time when it was recognized as the New Economic Sociology (Granovetter, I985; Swedberg, I997), stood out for its particular use of embeddedness, synthesized in the following excerpt, which sets the tone for the debate in TI (Granovetter, I985: 482-483):

I assert that the level of embeddedness of economic behavior is lower in nonmarket societies than is claimed by substantivists and development theorists, and it has changed less with 'modernization' than they believe; but I argue also that this level has always been and continues to be more substantial than is allowed for by economists and formalists.

In this vein, Granovetter inaugurates an intellectual response to the incursion of economics into the realm of sociological issues (the so-called "economic imperialism," whose key author was Gary Becker). The concept would eventually be expanded through the identification of different types of embeddedness: structural, political, cognitive, and cultural (Zukin \& DiMaggio, I990). ${ }^{2}$ This expansion of the concept resulted in the incorporation of authors who until then had not taken part in the debate with Granovetter or even with Polanyi, comprising a relatively large number of studies cited in the main literature on this "refoundational" moment of the discipline (exempli gratia, Swedberg, I997). This literature includes the studies by Granovetter himself on the role of social networks in the functioning of labor markets (Granovetter, 1974) and about the electricity industry in the United States (Granovetter \& McGuire, I998); studies by Viviana Zelizer (1985, I994, 2005) on the social value of childhood, the social meaning of money, and the "purchase of intimacy", respectively; research by Neil Fligstein (I990) on the forms of control of the big corporations in the North-American economy and the comparative study by Dobbin (I994) about the relationship between political cultures and industrial development projects related to rail systems in the United States, Britain, and France. ${ }^{3}$ 
The work of Pierre Bourdieu (I997) is a singular case among this set of authors due to the way in which he incorporated the "economic field" into his research agenda. For the author, embeddedness means treating economic practices as a "total social fact," whose understanding mobilizes the concepts of habitus, social capital, symbolic capital, and field (Bourdieu, 2005: I-2). Economic action is thereby interpreted in terms of dispositions produced within historical and cultural processes. Bourdieu thus demonstrates a "double construction" of the market, mainly based on a case study of the market for individual houses, where agents' behavior, from both the supply and the demand sides, is found to be the outcome of dispositions inscribed in collective dynamics driven by the state and, in a wider sense, by disputing forces within the economic field (Bourdieu, I997, 2005; Lebaron, 200I).

A critical assessment of the transformations in course in late-twentiethcentury capitalism, including the alleged institutional convergence towards liberal market capitalism propelled by globalization, constitutes a further chapter of Ti. Under the rubric of the "comparative capitalisms" approach (Deeg \& Jackson, 2007), this line of research aimed to scrutinize the impact of globalization on national, regional, or sectoral economic arrangements, comparing the similarities and differences between specific trajectories within each of these dimensions. Aligned with the notion of the "social construction of the economy," one of the themes privileged by this literature is the identification of specific forms of organizing production and their "institutional embeddedness," including issues such as distributional conflict, labor relations, and inter-firm relations. Hence, this strand of research sought to demonstrate the persistent institutional diversity of capitalism, despite tendencies towards convergence being identified - or at least defended - by mainstream economic approaches to globalization (see Ferrer, I997). Examples of research that has challenged those arguments supporting the view that economic institutions should converge towards a liberal market economy thus include studies of economic governance at sectoral level (Campbell, Hollingsworth \& Lindberg, I99I; Hollingsworth, Schmitter \& Streeck, I 994), "social systems of production" (Hollingsworth \& Boyer, I997), "varieties of capitalism" (Hall \& Soskice, 200I), and the relationship between state and business in the construction of joint development projects (Evans, I995). Pursuing this approach, these works demonstrate both the vitality and the persistence of diversified types of market economy, all of them embedded in more or less robust institutional arrangements that provide resilience to the pressures generated by globalization, thus allowing them to pursue development trajectories distinct from those advocated by the so-called Washington Consensus. ${ }^{4}$

The turn of the 2000s, however, brought a new wave of interpretations concerning the concept of embeddedness that would mark the limits to the approach introduced by Granovetter (I985). In this sense, Krippner (200I) pro- 
poses no less than relinquishing the concept as the main theoretical tool of economic sociology, arguing that the "intuition" that markets are socially embedded has beguiled economic sociologists into neglecting a more robust theorization of the market itself, which continues to be taken for granted. Thus, even though Granovetter, in his I 985 article, criticized Parsons's conceptualization of the problem of order, Krippner maintains that he stuck to the Parsonian intellectual division of labor between sociology and economics, failing to theorize the market per se (Kripnner, 200I; Krippner \& Alvarez, 2007). Granovetter, in this sense, was much more interested in observing the connection between individuals and social networks, rather than in characterizing the institutional arrangement of the economic system (Dale, 2010). In other words, the large scale economic and political changes seen in modern society, spotlighted in the narrative of The great transformation, are absent from Granovetter's classic article (I985). 5 However, leaving aside from the Granovetterian approach, a "Polanyian" approach to embeddedness (Krippner, 200I; Krippner \& Alvarez, 2007) still persists, which privileges the dynamics of disembeddedness and re-embeddedness, as elaborated in Polanyi's discussion of the countermovements, and is more directly linked to the debate in $\mathrm{T} 2$.

\section{T2 - EMBEDDEDNESS AS DOUBLE MOVEMENT}

Notwithstanding Krippner's criticism, the concept of embeddedness remained pertinent to the debate on economic sociology during the first decade of the new century. At this moment, however, the debate was less about the "social construction of the economy" and more about the changes in the relationship between state and market engendered by globalization, with a special interest in neoliberalism and its impact on economic development and social solidarity. ${ }^{6}$ In this way, the emphasis lay on the expected abandonment of the Washington Consensus agenda, having acknowledged its failure to cope with the challenges posed by globalization, especially in developing countries. Symptomatically, it was in $200 \mathrm{I}$ that a new edition of The great transformation appeared, bearing a new introduction by economic sociologist Fred Block, a specialist in the debate on development and the state's role in the economy (Block, I994; Block \& Evans, 2005), as well as a preface by Joseph Stiglitz, former chief-economist of the World Bank, Nobel laureate in economics in the same year of 200I, and a critic of the approaches that had underpinned the market reforms of the previous years (Stiglitz, 2002; Chang, 200I). In both the preface (Stiglitz, 200I) and the introduction (Block, 200I), the authors highlight the ideological character of the economic prescriptions concerning the "retreat of the state," calling attention to their negative impacts on those societies where they have been implemented, and confronting such prescriptions with historical evidence of the persistent involvement of the state with the economy in both developed and developing countries, in both the past and the present. 
Thus, the interpretation of capitalism as a phenomenon marked by a pendular movement gained traction. Such a movement would mean the advancement of market logic - as disembeddedness - and, in response to the inevitable crises spawned by this dislocation, the subsequent return to re-embeddedness, a process dubbed the "gradational approach" by Gemici (2008: I5I9) and "the great oscillation" by Dale (2010: 226-230).7 The perspective of reembeddedness presupposes an interpretation of the economy as "always embedded," based on several passages in which Polanyi speaks of the utopian character of the market economy and its tendency to destroy society if it becomes fully realized - the "satanic mill." Along these lines, Block and Sommers, for example, argue that embeddedness is a substitute for politics, social relations, and institutions. According to the authors: "For Polanyi, an always-embedded market economy means that markets are always organized through politics and social practices" (Block \& Sommers, 20I4: Io, original italics).

Among the relevant reference works of $\mathrm{T} 2$ are the studies by Fred Block himself, focused on criticizing "market fundamentalism" and appealing for a greater engagement of economic sociology in the public scene (Block, 2007), as well as analyzing the public sector's capacity to promote and financially support the private sector in the formation of a national innovation system in the United States. This runs counter to a prevailing liberal view ("market fundamentalism" again) that envisages the US economy as an exemplary case of the kind of success achievable by free economic agents, allowing the author to speak of a "hidden developmental state" in the country (Block, 2008). In a theoretical vein, Evans (2010) engages in the debate on development in the twenty-first century by arguing for an expanded understanding of embeddedness elaborated in his previous work (Evans, I995): instead of an autonomous bureaucracy of a Weberian type, with formal and informal links to business imprinted in the "embedded autonomy" model, the author proposes a state qualified to increase citizen capacity, entailing more connections with civil society, as well as greater investment in deliberative institutions (Evans, 2003, 2008).

The literature on "comparative capitalisms," for its part, has also contributed to the debate on the central role of the state. The chapters in Coates (2005) and the analysis by Boyer (2005) of the common and divergent traits between the "comparative capitalisms" approach and regulation theory are prime examples in this direction. Referring to this agenda, Nölke (2012) explores the role played by the BRIC nations in contemporary capitalism in a context of neoliberalism in crisis (to follow the lead of the title of the volume in which the text appears). More specifically, the author discusses a potential reconfiguration of capitalism in the opposite direction to the liberal model prevailing until the turn of the 200os, probably towards a "BRICs variety of capitalism," in which the role of the state in the economy would become more salient. ${ }^{8}$ 
While in Ti the "comparative capitalisms" approach provoked little enthusiasm among Brazilian authors, in T2 this perspective stimulated several works - not all of them, it is worth noting, identified with economic sociology. Mainly based around political science, this perspective has converged with sociological arguments concerning the relevance of politics as an analytic key to understanding globalization, highlighting the importance of institutional arrangements and strategic choices as factors explaining the way in which Brazil participated in economic globalization, both from a general perspective (Diniz, 2000; Velasco e Cruz, I998), and from the viewpoint of specific economic sectors (Monteiro, 20I I Leme, 2009). The "comparative capitalisms" approach typically practiced in Brazil during T2 explored the general idea of "varieties of capitalism" but did not necessarily demonstrate the institutional embeddedness of Brazilian capitalism's key actors, especially in the case of firms. The chapters in Boschi (20I I), for example, stress the choices made by strategic actors in the state bureaucracy of Brazil and other selected countries, identifying alternative development paths that disprove the hypothesis of convergence towards a single liberal model (see also Bresser-Pereira, 20I I). From the viewpoint of the public debate, these studies supported the return to state activism, understood as a form of re-embeddedness, after the cycle of liberalization underscored by pro-market reforms. In a "post-Washington Consensus" context (Diniz, 2007), an emergent "neo-developmentalism" model would be explored (Bresser-Pereira, 20I6) as a strategy capable of responding to the challenges posed by twenty-first-century capitalism.

In spite of the reverberation of the debate, which includes an approximation with the agenda of heterodox economists like Stiglitz, Chang, and Boyer, among others, the expectation of re-embeddedness represented by the restoration of the state's protagonism far from confirmed the defeat of neoliberalism. The task of understanding the complex relationship between neoliberalism and society would have to begin by questioning the interpretation of neoliberalism as merely the "retreat of the state," foregrounding its moral and normative dimension, as will be seen in the next section.

\section{T3 - EMBEDDEDNESS IN DISEMBEDDEDNESS}

T3 of the debate on embeddedness brings disembeddedness centerstage, not as a "moment" in the relationship between market and society, subject to the ebbs and flows of historical processes, but as a distinctive trait of capitalism

- that is, as a disruptive historical phenomenon, against the arguments in T I and T2, anchored in the presupposition of an "always embedded" economy. In this sense, Dale (2010) highlights the confusion over the methodological meaning of the concepts of embeddedness and disembeddedness: are they empiricaldescriptive terms or ideal types used for comparative ends? Such ambiguity resonates with the influence on Polanyi from Marx, Tönnies, and Weber, oscil- 
lating between Marx and Weber. Dale, who inclines towards the Marxist interpretation, contends that what defines Polanyi's work is his capacity to demonstrate that, in addition to the fact that the economy is embedded in society in a wider sense, in market society, it is the economy's isolation from non-economic institutions that matters. Authors who favor the disembeddedness approach also argue that saying the economy is "instituted" (Polanyi, Arensberg \& Pearson, I957: 243-270) is not the same as saying it is embedded (Machado, 20I0; Cangiani, 20I I). So, for example, Machado (2010) stresses that while Block refers to state intervention as evidence of the "always embedded" approach, it was Polanyi himself who demonstrated the pivotal role of the state in the process of disembeddedness that produces market society. Cangiani (20I I), in turn, underscores the need to distinguish "disembeddedness as instituted process" from the pure theory of abstract neoclassical models - it is the latter that possesses a utopian character and, therefore, cannot exist. It is precisely because disembeddedness is instituted - that is, because it becomes a reality - that society produces the counter-movements that "gives the social system its typical dynamics and complexity" (Cangiani, 20II: I9I). In this vein, the author concludes in favor of the disembeddedness approach and delineates the core issue of $\mathrm{T} 3$ as follows:

The history of our society is to be considered as an irreversible process of institutional change, which is complex and indeterminate, but constrained by the need to reproduce the most general institutional features, that is, market- and capitalist relations, and therefore a disembedded economy (Cangiani, 20II: I92)

This point of view introduces a new perspective on contemporary capitalism, globalization, and neoliberalism, and has inspired more authors to take part in the debate on the meaning of embeddedness and its opposite, disembeddedness. On one side, those who emphasize Polanyi's detachment from the Marxist tradition in which he was formed (Block \& Sommers, 20I4; Burawoy, 2010); 9 and, on the other, those who reinforce his Marxist inspiration, emphasizing the market economy's institutional specificity, whose distinctive trait is precisely the separation of the economic sphere from all others (Dale, 20Io; Cangiani, 20I I; Machado, 2010). ${ }^{\text {10 }}$

Despite the aforementioned differences, it is worth noting the virtual consensus among these authors regarding the ways to cope with - or even to supersede - the destructive impacts of disembeddedness. Burawoy, for example, envisages an escape from the threats of the market logic via a socialism built "through the molecular transformation of civil society," which would open the way to constructing "small scale views of alternatives such as cooperatives, participatory budgeting, and universal income grants" (Burawoy, 201 3: 47). Block and Sommers (2014), for their part, refer to the search for alternatives through the radicalization of democracy, which should entail the adoption of a series of strategies, such as "parliamentary institutions elected on a territorial basis," 
participative institutions through which "citizens would directly influence the allocations made by local governments [...] participation of employees in the governance of the workplace," and also "the creation of local economic institutions that would give citizens direct voice in the patterns of economic development" (Block \& Sommers, 20I4: 238). Lastly, Dale (2010: 234) recognizes the strength of the financial and business interests driving the neoliberal project, but stresses that such interests do not assure its perpetuation, and concludes: "in order for neoliberalism to come to an end, powerful social movements would be necessary."

By following alternative paths, approaches focusing on the moral and normative dimensions of the economic order highlight the limits of an approach centered exclusively on the contradiction between the interests of civil society and the market logic that underpins neoliberalism. Contributions to the literature that help redefine the perspective on the issue include the performativist approach of Michel Callon (I998, 2007), when he talks about the "embeddedness of economic markets in economics," the works of Marion Fourcade and Kieran Healey concerning the forms of classification, valuation and status attribution engendered by the techniques and devices that organize markets in the contemporary world (exempli gratia, Fourcade, 20I I; Fourcade \& Healey, 2007, 2013, 20I7) and, from a broader perspective, the work of Dardot and Laval (2010) on neoliberalism as a "new way of the world." The principal insights from these authors include, firstly, a recognition that the state plays an active role in the production and reproduction of the neoliberal logic and in the strengthening of the market - something, it is worth noting, well established in the work of Karl Polanyi; and, secondly, their focus on the role of economic knowledge in the organization of social life under capitalism, eventually propped up by the advancement of information technologies, which have helped popularize market logic and indeed, by extension, neoliberalism. ${ }^{\text {II }}$

In this sense, neoliberalism assumes the condition of a moral-normative frame that generalizes the market economy logic throughout the social system, exporting the intelligibility of calculation and economization to all social relations and individual behaviors. The endeavor of the intellectuals of neoliberalism, especially North Americans, has been to apply the homo economicus form to all social actors, economic or not, converting them into "entrepreneur[s] of one's self" (Dardot \& Laval, 20I0). In this approach, moreover, neoliberalism ceases to be seen as mere ideology and becomes a power technology, a mirror of a political world (or a regime of governmentality) that diffuses the market model and establishes a mode of regulation determined not by the state, but by individual freedom (Gago, 20I8). In other words, individual behavior ceases to be externally and coercively regulated, and becomes internally regulated by the self-monitoring of the social actors (Fourcade \& Healey, 2007). In this way, faced with democracy's increasing incapacity to work as a barrier to market 
abuses, neoliberalism defines the radicalization of individual freedom and competition as its main pillars.

According to Fourcade and Healey (2007), the market can be seen as culture, not only because it is the product of human experience, but also because it is an explicitly normative moral project. Neoliberalism can be understood, therefore, not just as an expression of market society, historically embedded in the discourse of mainstream economics, but also as a moral category, in the sense of something that society defines either as legitimate or as inappropriate (Durkheim, I996). Economists have thus become the main purveyors of performativist techniques (Callon, I998; Fourcade \& Healey, 2007; Mackenzie, Muniesa \& Siu, 2007). As a moral-normative system, neoliberalism acts upon governments, firms, and above all individuals by imposing criteria for efficiency and normalizing the diffusion of competitive practices into all dimensions of social life, thus materializing "embeddedness in disembeddedness." As Dardot and Laval (2010) propose, neoliberalism thereby becomes the rationality of contemporary capitalism itself, producing a new model of social relations profoundly marked by individualization in detriment to more traditional forms of collective solidarity, such as trade unions, for example. In their interpretation of neoliberalism as a moral-normative system, strongly inspired by Foucault's original characterization, and in close connection to empirical analyses of the popularization of neoliberalism (Gago, 2018; Fridman, 20I6), Dardot and Laval demonstrate the operationalization of governmentality (the self-government of individuals) in the construction of a new pattern of subjectivity, identified with the notion of entrepreneurial subject. This entails a new understanding of individualism as a social value (Durkheim, I996; Dumont, I99I), ${ }^{12}$ with the incorporation of competition in the realm of social relations and the naturalization of inequality.

This understanding is shared by Gago (2018), who stresses the need to consider neoliberalism's resilience beyond the crisis in legitimacy of democratic politics, such that a more accurate definition of neoliberalism does not presume the freeing of the economic sphere from political influences. Hence, the process of disembeddedness that marks neoliberalism cannot be associated merely with autonomization of the economic field, but must be conjugated with "the creation of a political world (a governmentality regime) that appears as the 'projection' of rules and requirements of a competitive market" (Gago, 20I8: 235). Such a world persisted, for example, in Latin America during the 2000s, even after the election of progressive governments committed to a more active role of the state in the economy and critical of the excessive market deregulation of preceding years. Countries like Brazil and Argentina, with social-democratic governments in office for more than a decade, saw a significant advancement of the informal economy, financialization of the popular classes, and social inclusion through consumption, all of these processes evinc- 
ing the continuing expansion of market logic despite the "anti-neoliberalism" discourse of these governments (Gago, 2018).

Returning to the debate surrounding the "comparative capitalisms" approach that cuts across $\mathrm{T} I$ and $\mathrm{T} 2$, it is worth noting that some of its representative authors, when discussing the persistence of neoliberalism, turned to the analysis of capitalism's common traits (Streeck, 2010), in contrast to a previous focus on its diversity. Crouch (20I I), for example, discusses those characteristics specific to neoliberalism, and suggests that the traditional opposition between state and market must be complemented by a third party: big corporations. Irreducible to either of the other two poles, corporations actually subsume state and market as a result of their economic and political power. The author acknowledges the active role of the state in supporting the big corporations, but ultimately, he suggests, a re-invigoration of civil society and its institutions is the best way to recover forms of sociability that provide alternatives to neoliberalism. Streeck (20I4), in turn, identifies the recomposition of the power relations between capitalists and workers under contemporary capitalism, a process actually unfolding since the crisis in Fordism and the welfare state in the I970s, with capitalists reclaiming the lion's share of wealth production after a period during which they were forced to cede ground to workers. His argument is that the state had to "buy time" by resorting first to inflation and then to public debt, mechanisms through which it was possible to keep on financing welfare programs that, albeit under huge pressure, continued to exist in developed countries over the ensuing decades. More recently, this extra time had to be bought through an expansion of individual debt, increasing the pressure exerted by economic interests over people. His conclusion, however, is that the capacity to postpone the crisis is probably drawing towards an end, with the same true for the convergence between capitalism and democracy.

In parallel, other authors have continued to explore the issue of institutional diversity, though recognizing a general common tendency towards liberalization. In this direction, Thelen (20I4) refers to "varieties," less in terms of firms, as in Hall and Soskice (200I), and more in terms of the role of coalitions and political alignments in shaping social solidarity in a selected group of developed countries (United States, Germany, Denmark, Sweden, and the Netherlands), resulting in different "varieties of liberalization." The author's analysis incorporates what she calls a "Durkheimian/Polanyian" dimension, referring to the greater or lesser degree of social solidarity present in each case, which varies according to the level of equality/inequality resulting from each liberalization process. ${ }^{13}$ Thelen acknowledges the convergence of the selected countries towards a more liberalized model - the amplification of a market logic - but she also demonstrates that room exists for varied degrees of inequality, highlighting the cases of the United States, where inequality has grown exponentially; Germany, with the dualization of its economy (those industrial 
sectors able to maintain some degree of coordination and are relatively immune to the expansion of the market logic versus emergent or growing sectors subject to an expansion of market logic, in the service sector, for example); and Denmark, with the expansion of the market logic to all sectors, compensated by public policies on social security and employability. The latter provides an example of a more egalitarian society, an arrangement defined by the author as "embedded liberalization."

In short, the works of Crouch, Streeck, and the interpreters of Polanyi in favor of the disembeddedness approach, such as Dale, Block and Sommers, put forward a perspective strongly marked by a contradiction of interests between neoliberalism and civil society, insofar as market expansion tends to be associated with the precarization of social life. However, as works informed by the moral-normative approach to neoliberalism have demonstrated, social life has become strongly embedded within the neoliberal/market logic - an embeddedness in disembeddedness - even though the economic gains and social costs of such a socioeconomic arrangement remain unequally distributed (not a characteristic of neoliberalism alone, it should be added). In this sense, one area that may still provide insights for economic sociology in $\mathrm{T}_{3}$ is further investigation of the findings of the moral-normative approach. These can better inform the approaches more inclined to Marxism and/or "comparative capitalisms" regarding the relationship between civil society and neoliberalism. One promising path of investigation is to take more seriously the alignment of interests between workers and popular classes with the market logic, a phenomenon that should not be perceived as the naturalization or automatic alignment with inequality, as Thelen reminds us. Even if we take into account the arguments of Crouch and Streeck (1997) concerning the limits and contradictions between neoliberalism and the interests of workers and popular classes, and therefore, with democratic life, there would seem to be room for further investigation into the forms of "livelihood" (Polanyi, Arensberg \& Pearson, I957) that emerged with globalization and, following Thelen still, the strategies used to recompose social solidarity amid these new configurations.

Hence, the search for alternatives to neoliberalism must consider the centrality attributed by Polanyi to politics, especially his non-essentialist approach to social classes. As he emphasized (Polanyi, 200I: 20I-2 I9), capitalists supported countermovements when the market logic threatened their own interests. The debate in $\mathrm{T}_{3}$ shows that alignments can occur between the interests of civil society and market logic. Consequently, expectations concerning the best way to overcome the threats of disembeddedness, either by overthrowing capitalism or institutionally embedding it, need to take into account the distinctive trait of contemporary society: the extent to which it is embedded in the disembeddedness represented by market logic. 


\section{CONCLUDING REMARKS}

This article has discussed the ways in which the concept of embeddedness has been used in economic sociology, exploring its relationship to the correlate concepts of re-embeddedness and disembeddedness during three periods. The aim was to demonstrate how the concept remains relevant for economic sociology, in contrast to the arguments of Krippner and Alvarez (2007) and Gemici (2008). The "always embedded" approach typical of Ti, strongly influenced by the "Granovetterian" perspective, lost centrality, while in $\mathrm{T} 2$ the "always embedded" approach served not so much as a "methodological framing" useful for all sociological analyses of the economy, but rather as a premise intended to explain why, in the face of the disembeddedness promoted by neoliberalism, a process of re-embeddedness would inevitably follow, the result of countermovements represented by the efforts of the state and society to take back control of the market.

The discussion subsequently presented embeddedness as a dynamic concept underlying the debate on the relationship between state, market, and society. The article then moved to $\mathrm{T}_{3}$, focusing primarily on the relationship between embeddedness and disembeddedness. Based on the specific features of the market system, as per the interpretation of Cangiani and others, it is possible to distinguish a society increasingly embedded in a more and more disembedded economy. Based on this premise, the work discussed the autonomization of neoliberalism and the capacity of democratic institutions to curb its propensity to subsume social forces. Reaching the end of the third period, therefore, the discussion exposed the tension between the irreversibility of market autonomization through neoliberalism and its reframing by civil society.

It is worth noting that, although introduced by Michel Foucault in the late I970s, the moral and normative view of neoliberalism that underscores the idea of "embeddedness in disembeddedness" remained latent for a long while, particularly during the I990s and early 2000 s when the TI and T2 versions of the "always embedded" approach were dominant. The emergence of the "embeddedness in disembeddedness" perspective benefitted from interpretations of the popularization of neoliberalism that saw it as moral and normative system, which ultimately contributed to understanding a new model of the morality of individual economic behavior, assigning (neoliberal) subjects greater responsibility and autonomy for their actions. In this sense, disembeddedness and the imposition of a principle of self-control on individuals relied upon the performativity of economics in its role of describing and molding reality, converting individuals into "calculating agencies" (Callon, I 998; Fourcade \& Healey, 2007; Mackenzie, Muniesa \& Siu, 2007).

Lastly, it is notable that most of the authors linked to the Marxist interpretations of Polanyi and to the "comparative capitalisms" approach failed to discern the dissemination of values and representations of the neoliberal/mar- 
ket logic illuminated by the moral-normative approach. The prevailing assumption of an antagonism between civil society interests and market logic deserves to be confronted by a research agenda that takes into consideration the extent to which a market/neoliberal logic has penetrated society (or society has become embedded in it), as the moral-normative approach suggests. In this way, the different approaches to neoliberalism can cross-fertilize each other, opening space for a more productive theorization of the alignments and conflicts of interest that constitute contemporary capitalism. Notwithstanding differences between the approaches, embedded or disembedded, the economy continues to be an instituted process, which underscores the relevance of interests, conflicts, and coalitions as keys to understanding market society.

Received on 02/Apr/2020 | Revised on 08/Jan/202 I Approved on I5/Jan/202 I

Cristiano Monteiro is professor of the Departament of Sociology at Universidade Federal Fluminense, Brazil and has been affiliate faculty at the Graduate Program in Public Policies, Strategies and Development at Federal University of Rio de Janeiro, Brazil. His research areas are economic sociology, institutional analysis and economic development, and he has published articles and book chapters on regional development, labor relations in the automotive industry and state-market relationship in the air transportation industry.

Raphael Lima is professor of the Department of Multidisciplinary Studies in Volta Redonda, the Graduate Program in Administration and the Graduate Program in Sociology at Universidade Federal Fluminense, Brazil. He is CNPq Researcher 2 and Jovem Cientista do Nosso Estado/ Faperj. His areas of interest are economic sociology, sociology of development and sociology of work. He has recently published articles and book chapters on corporate strategies in the automotive sector. 


\section{NOTES}

* The authors acknowledge financial support from CNPq and FAPERJ and two anonymous reviewers from Sociologia \& Antropologia for their helpful suggestions.

I In terms of methodology, the article follows Krippner (200I) and Krippner and Alvarez (2007) in its selection of the relevant bibliography, and mobilizes authors in economic sociology and related areas, with a focus on the theoretical elaborations around the concept and/or its application to empirical research. It does not claim to offer a systematic review of the existing literature, with the choice of relevant authors converging mostly with Krippner and Alvarez (2007) and other papers with more or less similar objectives (exempli gratia, Fligstein \& Dauter, 2007).

2 See also Swedberg (I997) and Steiner (I999). From a different perspective, Beckert (I996: 829) also proposes a research project for economic sociology based on different types of embeddedness, associated with what the author defines as "social devices," namely: habits, institutions, structures, and power. The author more explicitly incorporates the issue of intentionality of the action in markets, and distinguishes his approach from neoclassical economics on the same matter with the proposition that such action is socially situated in a context of uncertainty. "Social devices" thus serve the purpose of providing stability for relationships, in an approach that, in this sense, looks to restore the Hobbesian problem of order.

3 Discussing these very same authors, Krippner (200I) places, on one side, the works of Granovetter, which, according to her, failed to grasp the social dimension of the markets since they continue to insist on the separation between the economic and social spheres that underlies the concept of embeddedness. On the other side, Krippner places authors such as Zelizer and Fligstein, who "endorse a broad and encompassing notion of the economy in which the terrain of the market is coterminous with the groundwork of society itself" (Krippner, 200I: 80I). In fact, the concept of the embeddedness does not even appear in the index to Fligstein's work (I990), while Granovetter and Polanyi are both absent from the references. In a later work, however, Fligstein (200I: I68) states: "The results 
presented here reinforce the general sense that market relations are embedded in social relations and that actions make sense only when understood from the context of these relations", citing Granovetter (1985). Neither does Zelizer make direct reference to the concept of embeddedness, though the links between her own work and that of Karl Polanyi are thoroughly discussed in Steiner (2007).

4 Krippner (200I) treats the literature on "comparative capitalisms" (in her wording, the "governance approach") as a "Polanyian" strand of the embeddedness approach, in opposition to the Granovetterian take. Differences aside, both manifest the aforementioned difficulty in theorizing the social dimension of the market. See also Krippner \& Alvarez (2007: 229-230).

5 See also Dale (2010) and Cangiani (20II). Eventually, Granovetter himself would acknowledge that his 1985 article did not directly engage in Polanyi's debate on embeddedness. He argues that his aim was to show the impact of social networks on social relations in which economic life is "embedded," contributing to the understanding of the links between micro- and macro-level theories (see Krippner et al., 2004: II3-II4).

6 It is worth noting that, at least from the point of view of some of the authors associated with the TI agenda, embeddedness lost its centrality. For example, in the volume The economic sociology of capitalism edited by Nee and Swedberg (2005), with contributions by authors such as Evans, Fligstein, Zelizer, and DiMaggio, the index lists only three references to the concept and two to Karl Polanyi throughout its more than four hundred pages.

7 By way of illustration, Block (200I) compares "disembeddedness" with the movement of stretching a "giant elastic band": "Efforts to bring about greater autonomy of the market increase the tension level. With further stretching, either the band will snap - representing social disintegration - or the economy will revert to a more embedded position" (Block, 200r: xxv).

8 In more recent work, Nölke continues to argue for the relevance of a state-led capitalism, China being the most relevant empirical case (other pertinent cases would be India and Brazil, or at least until a certain point in the 
latter's recent trajectory). This permits the author to propose an expansion of the "varieties of capitalism" typology to incorporate a "state-permeated" type (Nölke, 20I8). Although these references extrapolate the time frame of $\mathrm{T} 2$, they reveal the persistence of the theoretical and empirical (Polanyian) question about the centrality of the state in the organization of capitalism.

9 In fact, these approximations or detachments from Marxism also retain their nuances. Burawoy (20I0), for example, suggests that the "always embedded" interpretation belongs to a particular kind of approach, which he dubs "sociological Marxism," Gramscian in inclination, which foregrounds the cultural dimension of the institutional changes generated by the market logic.

Io Once again revealing the nuances of the interpretations, Machado is aligned with the disembeddedness approach without explicitly connecting Polanyi to Marxism, although, when discussing the prospect of overcoming the threats of disembeddedness, he does make reference to arguments of a Marxist flavor, specifically the construction of a "post-capitalist society, namely with the abolition of the fictitious commodified character of labor, land, and money" (Machado, 2010: 13).

I I The Foucauldian notion of governmentality (Foucault, 2004) inspires such an approach more or less directly, pointing to the incorporation of the market logic as a form of self-government, orienting the conduct of agents in a diffuse manner, thus challenging the thesis that the neoliberal logic is "imposed" on agents by external political injunctions such as economic policy, free trade, or, more generically, globalization.

I 2 When discussing modern ideology, Dumont (I99I) presents himself as a critic of economic liberalism. However, by treating individualism as an ideology, he sets himself apart from the Foucauldian perspective according to which individualism derives from a solid moral-normative system, and not only from a set of ideological devices. It is worth highlighting that for Dumont (I99I: 3I), Polanyi foresaw that liberalism forced the introduction of social safeguard measures, leading to what could be called a contemporary "post-liberalism." 
60

I3 Thelen distinguishes the institutions that organize the "varieties of liberalization" between those with a Williamsonian nature, whose emphasis is on the efficiency of the economic arrangements, and those of a Durkheimian or Polanyian nature, whose emphasis is on the capacity to promote social cohesion. Her theoretical model's specific contribution is to disaggregate coordination and egalitarianism, dimensions that appear in Hall and Soskice (200I) as if they were aggregate by definition. This way, Thelen talks about types of liberalization that are more or less egalitarian.

\section{BIBLIOGRAPHY}

Beckert, Jens. (I996). What is sociological about economic sociology? Uncertainty and the embeddedness of economic action. Theory and Society, 25, p. 803-840.

Benjamin, César. (2012). Nota da edição brasileira. In: Levitt, Kari. (ed.). A subsistência do homem e ensaios correlatos. Rio de Janeiro: Contraponto, p. 7-ıo.

Block, Fred. (2008). Swimming against the current: the rise of a hidden developmental state in the United States. Politics \& Society, 36/2, p. 169-206.

Block, Fred. (2007). Confronting market fundamentalism: doing "public economic sociology". Socio-Economic Review, 5/2, p. 326-334.

Block, Fred. (200I). Introduction. In: Polanyi, Karl. The great transformation. Boston: Beacon Press, p. xviii-xxxviii. Block, Fred. (1994). The roles of the state in the economy. In: Smelser, Neil \& Swedberg, Richard (eds.). The handbook of economic sociology. Princeton/New York: Princeton University Press/Russell Sage, p. 69i-7io.

Block, Fred \& Evans, Peter. (2005). The state and the economy. In: Smelser, Neil \& Swedberg, Richard (eds.). The handbook of economic sociology. 2 ed. Princeton/New York: Princeton University Press/Russell Sage, p. 505-55I.

Block, Fred \& Sommers, Margareth. (2014). The power of market fundamentalism: Karl Polanyi's critique. Cambridge, MA: Harvard University Press. 
Block, Fred \& Evans, Peter. (2005). The state and the economy. In: Smelser, Neil \& Swedberg, Richard (eds.). The handbook of economic sociology. 2 ed. Princeton/New York: Princeton University Press/Russell Sage, p. 505-55I.

Boschi, Renato. (20II). Variedades de capitalismo e desenvolvimento na América Latina. Belo Horizonte: UFMG.

Bourdieu, Pierre. (2005). The social structures of the economy. Cambridge: Polity Press.

Bourdieu, Pierre. (I997). Le champ économique. Actes de la Recherche en Sciences Sociales, II9, p. 48-66.

Boyer, Robert. (2005). How and why capitalisms differ? Economy and society, 34/4, p. 509-557.

Bresser-Pereira, Luiz Carlos. (2016). Teoria novo-desenvolvimentista: uma síntese. Cadernos do Desenvolvimento, II/I9, p. I45-I65.

Bresser-Pereira, Luiz Carlos. (20II). Cinco modelos de capitalismo, Escola de Economia de São Paulo. Textos para Discussão, 280.

Burawoy, Michael. (2013). Marxism after Polanyi. In: Williams, Michelle \& Satgar, Vishwas (eds.). Marxisms in the 2 Ist century: crisis, critique \& struggle. Johannesburg: Wits University Press, p. 34-52.

Burawoy, Michael. (2010). From Polanyi to Polyanna: the false optimism of global labor studies. Global Labor Journal, I/2, p. 30I-3I3.

Callon, Michel. (2007). What does it mean to say that economics is performative? In: Mackenzie, Donald; Muniesa, Fabien \& Siu, Lucia. (eds.). Do economists make markets? On the performativity of economics. Princeton: Princeton University Press, p. 3II-357.

Callon, Michel. (1998). Introduction: the embeddedness of economic markets in economics. In: The laws of the market. Oxford: Blackwell/The Sociological Review, p. I-55.

Campbell, John; Hollingsworth, Joseph Rogers \& Lindberg, Leon. (I99I). Governing the American economy. Cambridge: Cambridge University Press.

Cangiani, Michele. (20II). Karl Polanyi's institutional theory: market society and its "disembedded" economy. Journal of Economic Issues. 45/I, p. I77-I97. 
Chang, Ha-Joon (ed.). (200I). Joseph Stiglitz and the World Bank: the rebel within. London: Anthem Press.

Coates, David (ed). (2005). Varieties of capitalism, varieties of approaches. New York: Palgrave Macmillan.

Crouch, Colin. (20II). The strange non-death of neoliberalism. Cambridge: Polity Press.

Crouch, Colin \& Streeck, Wolfgang. (1997). Political economy of modern capitalism. Mapping convergence and diversity. London: Sage.

Dale, Gareth. (2010). Karl Polanyi: the limits of the market. Cambridge: Polity.

Dardot, Pierre \& Laval, Christian. (2010). La nouvelle raison du monde: essai sur la société néoliberale. Paris: La Découverte.

Deeg, Richard \& Jackson, Gregory. (2007). Towards a more dynamic theory of capitalist variety. Socio-economic review, 5/I, p. I49-I79.

Diniz, Eli. (2007). El post-consenso de Washington: globalización, Estado y desarollo reexaminados. Boletín Brasil, 4/I. Diniz, Eli. (2000). Globalização, reformas econômicas e elites empresariais. Rio de Janeiro: FGV.

Dobbin, Frank. (1994). Forging industrial policy: the United States, Britain, and France in the railway age. Cambridge: Cambridge University Press.

Dumont, Louis. (1991). Essai sur l'individualisme: une perspective anthropologique sur l'idéologie moderne. Paris: Seuil. Durkheim, Émile. (1996). De la division du travail social. Paris: Presses Universitaires de France.

Evans, Peter. (2010). The challenge of the 2Ist century development: building capability-enhancing states. New York: Global Event Working Paper.

Evans, Peter. (2008). Is an alternative globalization possible? Politics and Society, 36/2, p. 27I-305.

Evans, Peter. (2003). Além da monocultura institucional: instituições, capacidades e o desenvolvimento deliberativo. Sociologias, 9, p. 20-63.

Evans, Peter. (1995). Embedded autonomy: states and industrial transformation. Princeton: Princeton University Press. 
Ferrer, Aldo. (1997). Development and underdevelopment in a globalized world: Latin American dilemmas. In: Emmerij, Luis (ed.). Economic and social development into the XXI Century. Washington: Inter-American Development Bank.

Fligstein, Neil. (200I). The architecture of markets: an economic sociology of twenty-first century capitalist societies. Princeton: Princeton University Press.

Fligstein, Neil. (I990). The transformation of corporate control. Cambridge, MA: Harvard University Press.

Fligstein, Neil \& Dauter, Luke. (2007). The sociology of markets. Annual Review of Sociology, 33, p. I05-I28.

Foucault, Michel. (2004). Naissance de la biopolitique: cours au Collège de France (1978-1979). Paris: Seuil.

Fourcade, Marion. (20II). Cents and sensibility: economic valuation and the nature of "nature". American Journal of Sociology, II6/6, p. I72I-I777.

Fourcade, Marion \& Healey, Kieran. (2017). Seeing like a market. Socio-Economic Review, I5/I, p. 9-29.

Fourcade, Marion \& Healey, Kieran. (2013). Classification situations: life-chances in the neoliberal era. Accounting, Organizations and Society, 38, p. 559-572.

Fourcade, Marion \& Healey, Kieran. (2007). Moral views of market society. Annual Review of Sociology, 33, p. 285-3I I. Fridman, Daniel. (2016). Freedom from work: embracing financial self-help in the United States and Argentina. Stanford: Stanford University Press.

Gago, Verónica. (2018). A razão neoliberal: economias barrocas e pragmática popular. São Paulo: Elefante.

Gemici, Kurtulus. (2008). Karl Polanyi and the antinomies of embeddedness. Socio-Economic Review, 6/I, p. 5-33.

Granovetter, Mark. (1985). Economic action and social structure: the problem of embeddedness. American Journal of Sociology, 9I/3, p. 48I-5IO.

Granovetter, Mark. (I974). Getting a job: a study on contacts and careers. Cambridge, MA: Harvard University Press.

Granovetter, Mark \& McGuire, Patrick. (I998). The making of an industry: electricity in the United States. In: Callon, Michel (ed.). The law of markets. Oxford: Blackwell, p. I47-I73. 
Hall, Peter \& Soskice, David (eds.). (200I). Varieties of capitalism: The institutional foundations of comparative advantage. Oxford: Oxford University Press.

Hollingsworth, Joseph Rogers \& Boyer, Robert (eds.). (1997). Contemporary capitalism: the embeddedness of institutions. Cambridge: Cambridge University Press.

Hollingsworth, Joseph Rogers; Schmitter, Philippe \& Streeck, Wolfgang (eds.). (I994). Governing capitalist economies: performance and control of economic sectors. Oxford: Oxford University Press.

Krippner, Greta. (200I). The elusive market: embeddedness and the paradigm of economic sociology. Theory and Society, 30/6, p. 775-8Io.

Krippner, Greta \& Alvarez, Anthony. (2007). Embeddedness and the intellectual projects of economic sociology. Annual Review of Sociology, 33, p. 219-240.

Krippner, Greta et al. (2004). Polanyi Symposium: a conversation on embeddedness. Socio-Economic Review, 2/I, p. IO9-I35.

Lebaron, Frédéric. (200I). Toward a new critique of economic discourse. Theory, Culture and Society, I8/5, p. I23-I29. Leme, Alessandro. (2009). Estado e reformas orientadas para o mercado: compassos e (des)compassos na reestruturação do setor elétrico brasileiro na década de I990. Teoria e Pesquisa, I8/2, p. I8I-196.

Machado, Nuno. (2010). Karl Polanyi e a nova sociologia econômica: notas sobre o conceito de (dis)embeddedness. Revista Crítica de Ciências Sociais, 9o. Disponível em https:// journals.openedition.org/rccs/I77I. Acesso em Io dez. 2020. Mackenzie, Donald; Muniesa, Fabien \& Siu, Lucia. (2007). Introduction. In: Do economists make markets? On the performativity of economics. Princeton: Princeton University Press, p. I-I9.

Monteiro, Cristiano. (20II). Political dynamics and liberalization the Brazilian air transport industry: 1990-2002. Brazilian Political Science Review, 5/I I, p. 35-53.

Nee, Victor \& Swedberg, Richard (eds.). (2005). The economic sociology of capitalism. Princeton: Princeton University Press. 
Nölke, Andreas. (20I8). Dependent versus state-permeated capitalism: two basic options for emerging markets. International Journal of Management and Economics, 54/4, p. 269-282.

Nölke, Andreas. (2012). The rise of the 'B(R)IC variety of capitalism' - towards a new phase of organized capitalism? In: Overbeek, Heek \& van Apeldoorn, Bastiaan (eds.). Neoliberalism in crisis. London: Palgrave Macmillan, p. II7-I37. Polanyi, Karl. (200I) [1944]. The great transformation. Boston: Beacon Press.

Polanyi, Karl. (1977). The livelihood of man. New York: Academic Press.

Polanyi, Karl; Arensberg, Conrad \& Pearson, Harry (eds.). (I957). Trade and market in the early empires. Economies in history and theory. New York/London: The Free Press/Collier-Macmillan.

Steiner, Philippe. (2007). Karl Polanyi, Viviana Zelizer et la relation marchés/société. Révue du MAUSS, 29, p. 257-280. Steiner, Philippe. (1999). La sociologie économique. Paris: La Découverte.

Stiglitz, Joseph. (2002). Globalization and its discontents. New York: Norton \& Company.

Stiglitz, Joseph. (200I). Foreword. In: Polanyi, Karl. The great transformation. Boston: Beacon Press, p. vii-xvii.

Streeck, Wolfgang. (2014). Buying time: the delayed crisis of democratic capitalism. New York: Verso.

Streeck, Wolfgang. (20I0). E pluribus unum? Varieties and commonalities of capitalism. MPIfG Discussion Paper, Io/I2. Swedberg, Richard. (2003). Principles of economic sociology. Princeton: Princeton University Press.

Swedberg, Richard. (1997). Vers une nouvelle sociologie économique: bilan et perspectives. Cahiers Internationaux de Sociologie, CIII, p. 237-263.

Swedberg, Richard \& Granovetter, Mark. (I992). Introduction. In: The sociology of economic life. Boulder: Westview Press.

Thelen, Kathleen. (2014). Varieties of liberalization and the new politics of social solidarity. New York: Cambridge University Press. 
Velasco e Cruz, Sebastião. (1998). Alguns argumentos sobre reformas para o mercado. Lua Nova, 45, p. 5-27.

Zelizer, Viviana. (2005). The purchase of intimacy. Princeton: Princeton University Press.

Zelizer, Viviana. (I994). The social meaning of money. New York: Basic Books.

Zelizer, Viviana. (1985). Pricing the priceless child: the changing social value of children. New York: Basic Books.

Zukin, Sharon \& DiMaggio, Paul. (I990). Introduction. In: Structures of capital: the social structures of the economy. Cambridge: Cambridge University Press. 


\section{Palavras-chave \\ Karl Polanyi; mercado; economia política; instituições; solidariedade social.}

Keywords

Karl Polanyi; market; political economy; institutions; social solidarity.

\section{EMBEDDEDNESS E DISEMBEDDEDNESS NA SOCIOLOGIA ECONÔMICA EM TRÊS TEMPOS} Resumo

$\mathrm{O}$ artigo tem como objetivo demonstrar a permanência da relevância do conceito de embeddedness na sociologia econômica, colocando-o em perspectiva com a questão do disembeddedness por meio de uma análise em três tempos. O conceito introduzido por Karl Polanyi foi marcado, no primeiro tempo, por uma interpretação vinculada à noção de "construção social da economia". No segundo tempo, o debate se orientou para a crítica da agenda liberalizante do Consenso de Washington, sugerindo que os efeitos negativos dessa agenda para o desenvolvimento econômico e para a solidariedade social deveriam conduzir a uma retomada do controle do estado sobre a economia - o re-embeddedness. O terceiro tempo consiste no reconhecimento da especificidade da economia de mercado por meio de uma análise do neoliberalismo como arranjo político-institucional e sistema moral-normativo que produz "embeddedness no disembeddedness." O artigo também reflete sobre a possibilidade de restabelecimento da solidariedade social em uma economia crescentemente disembedded.

\section{EMBEDDEDNESS AND DISEMBEDDEDNESS IN ECONOMIC SOCIOLOGY IN THREE TIME PERIODS}

\section{Abstract}

The article sets out to demonstrate the continuing relevance of the concept of embeddedness in economic sociology, juxtaposing it with the question of disembeddedness through an analysis of three time periods. In the first period, the interpretation of the concept introduced by Karl Polanyi was marked by the notion of "social construction of the economy." In the second period, the debate focused on criticizing the liberalizing agenda of the Washington Consensus, suggesting that its negative effects on economic development and social solidarity would force the state to retake control of the economy, re-embedding it. The third period acknowledges the specificity of the market economy through an analysis of neoliberalism as a political-institutional arrangement and a moral-normative system that produces "embeddedness on disembeddedness." The article also discusses the re-establishment of social solidarity in an increasingly disembedded economy. 